\title{
MEDIASI SEBAGAI ALTERNATIF PENYELESAIAN SENGKETA PERBANKAN SYARIAH DI LUAR PENGADILAN (STUDI KASUS BPRS BHAKTI SUMEKAR)
}

\author{
Moh. Saleh Hadi Pradipta \& Asrori \\ Email: Saleh334@yahoo.com
}

\begin{abstract}
Abstrak
Penelitian ini membahas tentang beberapa cara dalam menangani seketa diluar pengadilan, diantaranya negosiasi, mediasi, konsiliasi, dan arbitrase. Namun, dalam penelitian ini lebih terfokuskan kepada proses peyelesaian sengketa diluar pengadilan dengan menggunakan metode mediasi. Penelitian ini juga menjelaskan tentang bagaimana proses mediasi dalam penyelesaian sengketa diluar pengadilan. memaparkan prinsip-prinsip dan dasar hukum pelaksanaan mediasi dalam menyelesaikan sengketa perbankan dilluar pengadilan. Penelitian ini bertempat di PT. BPRS Bhakti Sumekar.

Kualitatif diskriptif menjadi salah Metode gunakan oleh peneliti dalam melakukan penelitiand. dengan menggunakan metode kualitatif deskriptif. Metode kualitatif merupakan suatu paradigma penelitian untuk mendeskripsikan peristiwa, fenomena, perilaku orang atau suatu keadaan pada tempat tertentu secara rinci dan mendalam dalam bentuk narasi. Jenis penelitian ini adalah penelitian lapangan (field reseacrh). Pendekatan yang digunakan adalah Studi kasus merupakan salah satu jenis pendekatan kualitatif yang menelaah sebuah "kasus" tertentu dalam konteks atau setting kehidupan nyata kontemporer. Studi kasus merupakan jenis penelitian yang mendalam tentang individu, satu kelompok, satu organisasi, satu program kegiatan, dan sebagainya dalam waktu tertentu.

Hasil penelitian menemukan bahwa metode mediasi dalam penyelesaian sengketa perbankan diluar pengadilan sebagai salah satu bentuk alternatif dapat memenuhi kebutuhan masyarakat dalam penyelesaian sengketa perbankan. Terbukti dengan dibentuknya lembagalembaga yang menyediakakn jasa mediasi. Mekanisme penyelesaian sengketa antar nasabah dan Bank pada Bank Indonesia dapat ditempuh dengan dua tahap. Pertama, Bank ajib menyelesaikan terlebih dahulu sengketa dengan nasabahnya sesuai dengan peraturan Bank Indonesia (PBI) NO. 7/7/PBI/2005, tahap kedua adalah apabila sengketa belum dapat diselesaikan dengan baik, maka nasabah Bank dapat mengajukan permohonan penyelesaian sengketa melalui mediasi sesuai PBI No. 8/5/PBI/2006. metode mediasi dapat berjalan sesuai dengan fungsinya yaitu terbatas pada penyediaan tempat, membantu nasabah dan Bank untuk mengemukakan pokok permasalahan yang menjadi sengketa, penyediaan nara sumber, dan mengupayakan tercapainya kesepakatan penyelesaian sengketa antar nasabah dan Bank.
\end{abstract}

Kata Kunci : Mediasi, Sengketa perbankan, Pengadilan

\section{PENDAHULUAN}

Ekonomi syariah adalah usaha atau kegiatan yang dilakukan oleh orang perorang, kelompok orang, badan usaha yang berbadan hukum atau tidak berbadan hukum dalam rangka memenuhi kebutuhan yang bersifat komersial dan tidak komersial menurut prinsip syariah. ${ }^{1}$

Salah satu prinsip dalam ekonomi Islam adalah larangan riba, dan menggunakan sistem antara lain prinsip

\footnotetext{
${ }^{1}$ Mahkamah Agung RI, Peraturan Mahkamah Agung (PERMA) Nomor 2 Tahun 2008tentang Kompilasi Hukum Ekonomi Syariah, Edisi Revisi, (Direktorat Jenderal Badan Peradilan Agama, 2010) h.93
} 
bagi hasil. Dengan prinsip bagi hasil, bank syariah dapat menciptakan iklim investasi yang sehat dan adil karena semua pihak dapat saling berbagi baik keuntungan maupun potensi risiko yang timbul. Selanjutnya sesuai dengan ketentuan Pasal 1 angka 13 Undang-Undang Perbankan, yang disebut dengan prinsip syariah : Pembiayaan berdasarkan prinsip penyertaan modal (musyarakah), prinsip jual beli barang dengan memperoleh keuntungan (murabahah), atau pembiayaan barang modal berdasarkan prinsip sewa murni tanpa pilihan (ijarah), atau dengan adanya pilihan pemindahan kepemilikan atas barang yang disewa dari pihak bank oleh pihak lain (ijarah wa iqtina) $)^{2}$.

Sejak awal dilakukan perjanjian ekonomi, para pihak (kreditor dan debitor) dapat menentukan pemilihan forum atau lembaga penyelesai sengketa yang mungkin timbul di kemudian hari, baik dengan cara litigasi ataupun non litigasi. Hal ini sesuai dengan asas pacta sunt servanda bahwa setiap perjanjian yang menghendaki diperolehnya cara penyelesaian bila timbul sengketa yang dibuat oleh kedua belah pihak maka perjanjian tersebut mengikat kedua belah pihak.

Undang-undang Nomor 30 Tahun 1999 tentang Arbitrase dan Alternatif Penyelesaian Sengketa menyebutkan ada enam macam tata cara penyelesaian sengketa di luar peradilan, yaitu: ${ }^{3}$ Konsultasi, Negosiasi, Mediasi, Konsiliasi, Pemberian pendapat hukum dan Arbitrase.

Apabila para pihak dalam perjanjiannya menyatakan memilih penyelesaian sengketa secara non litigasi atau alternatif penyelesaian sengketa

2 Rachmadi Usman, Aspek Hukum Perbankan Syariah di Indonesia,( Jakarta: Sinar Grafika, 2012). h 115.

${ }^{3}$ Gunawan Widjaja, Seri Hukum Bisnis, Alternatif Penyelesaian Sengketa, (Jakarta: PT. Raja Grapindo Persada, 2005), h. 85 .
(Alternative Dispute Resolution), maka pengadilan secara absolut tidak berwenang mengadili perkara tersebut. ${ }^{4}$ Buku Pedoman Pelaksanaan Tugas dan Administrasi Peradilan Agama (Buku II) menegaskan, bahwa dalam memeriksa sengketa ekonomi syariah harus meneliti akta akad (transaksi) yang dibuat oleh para pihak, jika dalam akta akad (transaksi) tersebut memuat klausul yang berisi bahwa bila terjadi sengketa akan memilih diselesaikan oleh Badan Arbitrase Syari'ah Nasional (Basyarnas), maka Pengadilan Agama/Mahkamah Syar'iyah secara ex officio harus menyatakan tidak berwenang ${ }^{5}$. Penyelesaian sengketa secara non litigasi atau alternatif penyelesaian sengketa (Alternative Dispute Resolution), tunduk dan berlaku ketentuan Undangundang Nomor 30 Tahun 1999 tentang Arbitrase dan Alternatif Penyelesaian Sengketa.

Putusan lembaga arbitrase bersifat final dan mempunyai kekuatan hukum mengikat para pihak (final and binding), namun demikian terhadap putusan lembaga arbitrase dapat diajukan permohonan pembatalan dengan syarat limitatif yang ditentukan Undang-Undang Nomor 30 Tahun 1999. Permohonan dimaksud harus diajukan kepada Ketua Pengadilan Negeri. Namun demikian, dalam praktek hukumnya terdapat permohonan pembatalan putusan Badan Arbitrase Syari'ah Nasional (BASYARNAS) diajukan dan kemudian diputus oleh Pengadilan Agama Jakarta Pusat, dengan nomor perkara 792/Pdt.G/2009/PA.JP yang telah

${ }^{4}$ Pasal 3 Undang-Undang. Nomor 30 Tahun 1999 tentang Arbitrase dan Alternatif Penyelesaian Sengketa, dalam Himpunan Peraturan Perundang-undangan diLingkungan Peradilan Agama, ( Mahkamah Agung R.I.: Direktorat Jenderal Badan PeradilanAgama, 2014), h. 480.

${ }^{5}$ Mahkamah Agung R.I., Pedoman Pelaksanaan Tugas dan Administrasi PeradilanAgama (Buku II), Edisi Revisi, (Direktorat Jenderal Badan Peradilan Agama, 2013), h. 181 
menjatuhkan putusan atas perkara pembatalan Putusan Badan Arbritrase Syariah Nasional (BASYARNAS) Nomor 16/Tahun 2008/BASYARNAS/Ka.Jak, dengan Pemohon PT. BPRS Bhakti Sumekar melawan Majelis Arbiter Basyarnas dan PT. Atriumasta Sakti yang mendasarkan kewenangan lembaga peradilan tersebut dalam mengadili perkara di bidang ekonomi syari'ah, dengan membuat penafsiran hukum tentang kewenangan Pengadilan Negeri menjadi kewenangan Pengadilan Agama, sepanjang pokok sengketanya berkait dengan ekonomi syari'ah.

Bahwa, kewenangan sebagai penyelesai sengketa di bidang perbankan syariah, juga dimuat dalam Pasal 55 Undang-Undang Nomor 21 Tahun 2008 tentang Perbankan Syari'ah, sebagai berikut ;

(1) Penyelesaian sengketa Perbankan Syariah dilakukan oleh pengadilan dalam lingkungan Peradilan Agama.

(2) Dalam hal para pihak telah memperjanjikan penyelesaian sengketa selain sebagaimana dimaksud pada ayat (1), penyelesaian sengketa dilakukan sesuai dengan isi Akad.

(3) Penyelesaian sengketa sebagaimana dimaksud pada ayat (2) tidak boleh bertentangan dengan Prinsip Syariah.

Setelah adanya Putusan Mahkamah Konstitusi Nomor 93/PUU-X/2012 Tanggal 29 Agustus 2013, semakin menegaskan kewenangan absolut peradilan agama di bidang ekonomi syariah.

Bahwa, Putusan Pengadilan Agama Jakarta Pusat Nomor 792/ Pdt.G/ 2009/PA.JP tersebut kemudian dibatalkan oleh putusan banding di Mahkamah Agung RI dengan putuan nomor 188K/ AG/2010 tanggal 09 Juni 2010 dengan alasan Pengadilan Agama tidak berwenang memeriksa dan mengadili putusan BASYARNAS yang telah berkekuatan hukum (final and binding), sebagaimana Pasal 70, 71 dan 72 Undang-Undang No.
30 Tahun 1999 tentang Arbitrase dan Alternatif Penyelesaian Sengketa yaitu mengajukan permohonan pembatalan kepada pengadilan negeri.

Keberadaan bank dalam perekonomian modern sudah menjadi kebutuhan yang sulit dihindari, karena bank sudah menyentuh kebutuhan setiap orang dan seluruh lapisan masyarakat. Kalau dahulu masyarakat masih dapat menyimpan uang di bawah bantal atau dalam sebuah celengan yang terbuat dari gerabah, saat ini masyarakat akan lebih senang menyimpan uang di bank, karena uang tersebut dapat menghasilkan bunga dan lebih aman. Sementara itu, masyarakat yang membutuhkan dana akan lebih mudah datang ke bank daripada mencari orang yang dapat dan mau meminjamkan dana kepada yang memerlukan. Bank sebagai badan usaha yang menghimpun dana dari masyarakat dan menjalankan usahanya terutama dari dana masyarakat dan kemudian menyalurkan kembali kepada masyarakat. Selain itu, bank juga memberikan jasajasa keuangan dan pembayaran lainnya. Dengan demikian ada dua peranan penting yang dimainkan oleh bank yaitu sebagai lembaga penyimpan dana masyarakat dan sebagai lembaga penyedia dana bagi masyarakat dan atau Dunia usaha.

Sektor perbankan syariah memiliki peranan yang sangat vital, antara lain sebagai pengatur urat nadi perekonomian nasional. Lancarnya aliran uang sangat diperlukan untuk mendukung kegiatan ekonomi. Dengan demikian, kondisi sektor perbankan syariah yang sehat dan kuat penting menjadi sasaran akhir dari kebijakan di sektor perbankan syariah. Peran sektor perbankan syariah dalam pembangunan juga dapat dilihat pada fungsinya sebagai alat transmisi kebijakan moneter. Disamping itu, perbankan syariah merupakan alat yang sangat vital dalam penyelenggarakan transaksi pembayaran, baik nasional maupun internasional. Mengingat pentingnya fungsi itu, maka upaya menjaga 
kepercayaan masyarakat terhadap perbankan syariah menjadi bagian yang sangat penting untuk dilakukan. Dalam dunia perbankan syariah, nasabah merupakan konsumen dari pelayanan jasa perbankan syariah. Kedudukan nasabah dalam hubungannya dengan pelayanan jasa perbankan syariah, berada pada dua posisi yang dapat bergantian sesuai dengan sisi mana mereka berada. lihat dari sisi pengerahan dana, nasabah yang menyimpan dananya pada bank baik sebagai penabung deposan, maupun pembeli surat berharga, maka pada saat itu nasabah berkedudukan sebagai kreditur bank.

Sedangkan pada sisi penyaluran dana, nasabah peminjam berkedudukan sebagai debitur dan bank sebagai kreditur. Dari semua kedudukan tersebut, pada dasarnya nasabah merupakan konsumen dari pelaku usaha yang menyediakan jasa di sektor usaha perbankan syariah.

Seiring dengan pertumbuhan dunia usaha dan kebutuhan masyarakat akan produk serta jasa bank, bisnis perbankan syariah kini kian kompleks. Kompleksitas bisnis bank dapat dilihat baik dari sisi produk dan layanan maupun dari jaringan usaha dengan lembaga yang dibangun bank guna memperkuat daya tarik produk dan layanan bank yang bersangkutan. Kita dapat merasakan bahwa setiap bank melakukan penambahan outlet, fitur dan benefit produk banknya. Bekerjasama dengan beberapa lembaga non bank, dengan beberapa mitra usaha seperti Telkom, Telkomsel, PLN, Indovision/Cable Vision dan sebagainya. Upaya pengembangan fitur produk, layanan maupun jaringan usaha yang dilakukan setiap bank, akan menambah jumlah interaksi nasabah dengan bank. Semakin banyaknya interaksi bisnis antara nasabah dengan bank, maka semakin banyak pula peluang terjadinya keluhan, pengaduan bahkan sengketa finansial antara nasabah dengan bank.

Pada laporan yang terkait dengan sengketa antara nasabah dan perbankan syariah, BI mencatat adanya kenaikan pengaduan ke BI. Dibandingkan dengan data 2006, data hingga Februari 2008 terjadi peningkatan pengaduan ke BI sebesar 280\%. Pengaduan terkait penyaluran dana menurut data BI meningkat $441 \%$ yang sebagian besar terkait dengan kredit konsumsi.

Sejak diberlakukannya PBI mediasi perbankan syariah, BI telah menerima laporan sebanyak 262 kasus, dan 222 kasus telah diselesaikan. Sedangkan 40 kasus masih dalam proses. Hal ini berawal dengan terjadinya komplain yang diajukan nasabah kepada bank karena merasa dirugikan secara finansial. Upaya yang dilakukan nasabah antara lain dengan datang langsung ke bank, menelpon pada call center bank yang bersangkutan, menulis di media cetak misalnya pada surat pembaca, atau menyampaikan keluhan secara tertulis langsung kepada bank. Di sisi lain terkadang ada bank yang kurang memperhatikan pengaduan nasabah, atau bahkan mengabaikannya. Sengketa finansial dapat terselesaikan dengan beberapa cara. Disamping melalui cara litigasi, juga dapat dilakukan dengan cara mediasi. Cara ligitasi sebagaimana praktek selama ini, disamping memiliki kelebihan juga dapat kekurangan, antara lain mengenai proses, biaya dan waktu. Untuk menutup kekurangan cara litigasi inilah muncul cara mediasi yang selama ini terbukti produktif dalam menyelesaikan sengketa finansial antara nasabah dengan bank.

Sedangkan dari peraturan perundang-undangan di bidang perbankan syariah ketentuan yang memberikan perlindungan hukum bagi nasabah bank selaku konsumen antara lain adalah dengan diintrodusirnya Lembaga Penjamin Simpanan (LPS) dalam Undang-Undang Nomor 10 Tahun 1998, yaitu sebagai badan hukum yang menyelenggarakan kegiatan penjaminan atas simpanan Nasabah Penyimpan, melalui skim asuransi, dana penyangga, atau skim lainnya. Di tingkat teknis payung hukum 
yang melindungi nasabah antara lain adanya pengaturan mengenai penyelesaian pengaduan nasabah dan mediasi perbankan syariah dalam Peraturan Bank Indonesia (PBI).

Mengingat penyelesaian pengaduan nasabah oleh bank yang diatur dalam PBI Nomor 7/7/PBI/2005 tertanggal 20 Januari 2005 tentang Penyelesaian Pengaduan Nasabah tidak selalu dapat memuaskan nasabah dan apabila tidak segera ditangani dapat mempengaruhi reputasi bank, mengurangi kepercayaan masyarakat pada lembaga perbankan dan merugikan hakhak nasabah, maka perlu dibentuk lembaga Mediasi yang khusus menangani sengketa perbankan. Ada dua masalah dominan yang sering dikeluhkan konsumen jasa perbankan syariah. Pertama, pengaduan soal produk perbankan syariah, seperti ATM (Automatic Teller Machine), Kartu Kredit, dan aneka ragam jenis tabungan, termasuk keluhan produk perbankan syariah terkait dengan janji hadiah dan iklan produk perbankan syariah. Kedua, pengaduan soal cara kerja petugas yang tidak simpatik dan kurang profesional khususnya petugas service point, seperti teller, customer service, dan satpam.

Penelitian dalam bahasa Inggris disebut dengan research, yang pada hakekatnya merupakan sebuah upaya pencarian. Lewat penelitian (research) orang mencari (search) temuan-temuan baru, berupa pengetahuan yang benar (truth, true knowledge), yang dapat dipakai untuk menjawab suatu pertanyaan atau untuk memecahkan masalah. ${ }^{6}$

Morris L. Cohen \& Kent C. Olson dalam buku Legal Research, mengemukakan bahwa "legal research is an essential component of legal practice. It is the process of finding the law that governs an activity and materials that explain or analyze that law" (Penelitian hukum adalah komponen penting dari pada

6 M. Syamsuddin, Operasionalisasi Penelitian Hukum, (Jakarta : PT. RajaGrafindo Persada, 2007), h. 1. praktek hukum. Penelitian Hukum adalah proses dalam menemukan hukum yang mengatur kegiatan dan material yang dijelaskan dan dianalisa dengan hukum). ${ }^{7}$

Penelitian ini adalah penelitian ilmu hukum yang merupakan komponen penting dari praktek hukum, ini merupakan proses untuk menemukan hukum yang mengatur suatu aktivitas yang menjelaskan atau menganalisa hukum material tersebut. Menurut Peter Mahmud Marzuki, penelitian hukum adalah suatu proses untuk menemukan aturan hukum, prinsip-prinsip hukum, maupun doktrindoktrin hukum guna menjawab isu hukum yang dihadapi. Hal ini sesuai dengan karakter perfektif ilmu hukum. ${ }^{8}$

Adapun jenis penelitian yang dipakai dalam kajian ini adalah penelitian hukum kualitatif yang mempelajari masalah-masalah yang ada serta tata cara kerja yang berlaku dan bertujuan untuk mendeskripsikan apa-apa yang saat ini berlaku. Didalamnya terdapat upaya mendeskripsikan, mencatat, menganalisis dan menginterpretasikan kondisi yang sekarang ini terjadi. Dengan kata lain, penelitian deskriptif kualitatif ini bertujuan untuk memperoleh informasi-informasi mengenai keadaan yang ada. ${ }^{9}$

Ada dua jenis penelitian hukum yang dikemukakan oleh Soerjono Soekanto, yaitu penelitian hukum normatif dan penelitian hukum empiris atau sosiologis. ${ }^{10}$ Karena itu penelitian yang digunakan dalam kajian ini adalah penelitian hukum normatif adalah penelitian hukum doktrinal atau disebut

${ }^{7}$ Morris L. Cohen \& Kent C. Olson, Legal Resarch, (ST. Paul The United States of America : In A Nutshell, West Group, 2000), p. 1.

${ }^{8}$ Peter Mahmud Marzuki, Penelitian Hukum, (Jakarta : Prenada Media, 2005), h. 35.

${ }_{9}$ Mardalis, Metode Penelitian Suatu Pendekatan Proposal, (Jakarta : Bumi Aksara, 1999), h. 29.

10 Soerjono Soekanto dan Sri Mamudji, Penelitian Hukum Normatif, (Jakarta : PT. Raja Grafindo Persada, 2006), h. 31. 
juga sebagai penelitian perpustakaan. Disebut penelitian hukum doktrinal karena penelitian ini dilakukan atau ditujukan pada peraturan-peraturan yang tertulis atau bahan-bahan hukum yang lain, sedangkan disebut sebagai penelitian perpustakaan atau studi dokumen karena penelitian ini lebih banyak dilakukan pada bahan hukum yang bersifat sekunder yang ada di perpustakaan. ${ }^{11}$

Untuk melalukan penelitian ini penulis memerlukan data-data yang terkait dengan subyek penelitian. Adapun sumber data yang dipergunakan dalam penelitian ini berasal dari :

1. Sumber data primer. Sumber bahan hukum penelitian ini berasal dari penelitian kepustakaan (library research). Penelitian kepustakaan ini dilakukan terhadap berbagai macam sumber bahan hukum yang dapat digolongkan atas bahan buku primer dan bahan hukum sekunder.

2. Sumber data sekunder. Data sekunder bidang hukum dari sudut kekuatan mengikatnya dibedakan menjadi tiga golongan, yakni bahan hukum primer, bahan hukum sekunder, dan bahan hukum tersier $^{12}$, yaitu :

a) Bahan hukum primer, yaitu peraturan perundang-undangan perbankan dan perbankan syari'ah yang memberikan petunjuk dan penjelasan mengenai eksekusi hak tanggungan. Sumber bahan primer tersebut adalah :

1)

2)

3)

Undang-Undang Dasar Negara Republik Indonesia Tahun 1945;

Undang-Undang Nomor 4

Tahun 1996 tentang Hak Tanggungan;

Tahun 1989 tentang Peradilan Agama sebagaimana diubah dengan UndangUndang Nomor 3 Tahun 2006 dan Undang-Undang Nomor 50 Tahun 2009;

Undang-Undang Nomor 7

Tahun 1992 tentang Perbankan

11 Bambang Waluyo, Penelitian Hukum Dalam Praktek, (Jakarta : Sinar Grafika, 1991), h.l.

12 Soerjono Soekanto dan Sri Mamudji, Penelitian...., h. 33.

sebagaimana diubah dengan UndangUndang Nomor 10 Tahun 1998;

6)

Hukum Perdata;

7)

Agung Nomor 2 Tahun 2008 tentang

Kompilasi Hukum Ekonomi Syariah;

p

Putusan Pengadilan

Negeri Lamongan Nomor 27/Pdt.Plw/ 2014/PN. Lmg.

b) Putusan Pengadilan Negeri Cilacap Nomor 64/Pdt.G/2013/PN. Clc.

c) Putusan Pengadilan

Negeri Medan Nomor 88/Pdt.Plw/2012/PN. Mdn.

d) Putusan Mahkamah

Agung RI., Nomor 2479 K/Pdt/2011.

e) Penetapan Eksekusi Hak

Tanggungan Syariah Mahkamah Syariah Biereun Nomor 0010/Pdt.G/Eks/2015/Ms. Bir.

b) Bahan hukum sekunder, yaitu bahan hukum yang memberikan penjelasan mengenai bahan hukum primer, yang dikutip dari pendapat para ahli yang termuat dalam buku, majalah dan hasil penelitian.

c) Bahan hukum tersier, yaitu bahan hukum yang memberikan petunjuk sekaligus terhadap sumber hukum primer dan sekunder, seperti kamus hukum, kamus ekonomi, kamus bahasa Indonesia serta ensiklopedi di bidang hukum.

a. Data Penelitian

Adalah suatu langkah yang dilakukan untuk memperoleh data yang akan digunakan sebagai bahan penelitian. Dalam teknik pengumpulan data ada 3 cara yaitu :

a. Dengan cara Observasi. "Observsi adalah pengamatan dan pencatatan secara 
sistematik terhadap unsur-unsur yang tampak dalam suatu gejala atau gejalagejala pada obyek penelitian". Adanya observasi peneliti dapat mengetahui kegiatan pengamen jalanan yang berada di Surakarta, dalam kesehariannya melakukan mengamen. Berdasarkan pemaparan di atas dapat ditarik kesimpulan bahwa observasi merupakan kegiatan pengamatan dan pencatatan yang dilakukan oleh peneliti guna menyempurnakan penelitian agar mencapai hasil yang maksimal.

b. Dengan cara Wawancara. Pengertian wawancara sebagai berikut: Wawancara digunakan sebagai teknik pengumpulan data apabila peneliti akan melaksanakan studi pendahuluan untuk menemukan permasalahan yang harus diteliti, dan juga peneliti ingin mengetahui hal-hal dari responden yang lebih mendalam dan jumlah respondennya sedikit/kecil. Wawancara yang digunakan dalam penelitian ini dengan mengajukan pertanyaanpertanyaan terstruktur karena peneliti menggunakan pedoman wawancara yang disusun secara sistematis dan lengkap untuk mengumpulkan data yang dicari. Pada penelitian ini dilakukan wawancara tidak tersetruktur dengan Officer gadai PT. BPRS Bhakti Sumekar.

c. Dokumentasi adalah informasi yang berasal dari catatan penting baik dari lembaga atau organisasi maupun dari perorangan. Dokumentasi penelitian ini merupakan pengambilan gambar oleh peneliti untuk memperkuat hasil penelitian. Dokumentasi bisa berbentuk tulisan, gambar atau karya-karya monumentel dari seseorang. Dokumentasi merupakan pengumpulan data oleh peneliti dengan cara mengumpulkan dokumendokumen dari sumber terpercaya yang mengetahui tentang narasumber, misal bukti surat gadai. Metode dokumentasi yaitu mencari data mengenai variabel yang berupa catatan, transkrip, buku, surat kabar, majalah, prasasti, notulen rapat, agenda dan sebagainya. Berdasarkan kedua pendapat para ahli dapat ditarik kesimpulan bahwa pengumpulan data dengan cara dokumentasi merupakan suatu hal dilakukan oleh peneliti guna mengumpulkan data dari berbagai hal media cetak membahas mengenai narasumber yang akan diteleti. ${ }^{13}$

b. Teknik Pengumpulan Data

Metode pengumpulan data merupakan langkah yang paling strategis dalam penelitian, karena inti dari sebuah penelitian adalah untuk memperoleh atau mendapatkan data. Adapun teknik pengumpulan data (bahan hukum) yang digunakan dalam penelitian ini adalah pengumpulan bahan hukum dilakukan melalui studi pustaka yang meliputi bahan hukum primer yaitu perundang-undangan yang relevan dengan permasalahan, dan bahan hukum sumber sekunder yaitu bukubuku literature ilmu hukum serta tulisantulisan hukum lainnya yang relevan dengan permasalahan.

Studi pustaka dilakukan melalui beberapa tahapan yaitu pertama, editing, adalah memeriksa dan menelaah kembali semua data yang telah terkumpul yang relevan dengan pokok bahasan tesis. Kedua, organizing, yaitu melakukan analisa lanjutan terhadap hasil bahasan yang sudah direncanakan sebelumnya dan disesuaikan dengan rumusan masalah. Ketiga, actuating, yaitu melakukan penemuan hasil dengan menganalisa lanjutan terhadap hasil pengorganisasian data guna merumuskan kesimpulan.

Interpretasi data menurut L. R. Gay adalah suatu usaha yang dilakukan untuk menemukan arti atau jawaban dari data. Tujuan dari interprestasi data untuk menjawab 4 pertanyaan yaitu: 1 . Apa yang penting dari data itu? 2. Mengapa itu penting? 3. Apa yang bisa dipelajari dari data itu?, 4. Jadi apa?. ${ }^{14}$ Dengan demikian

13 Jonathan Sarwono, Metode Penelitian Kuantitatif dan Kualitatif, (Yogyakarta : Graha Ilmu, 2006), h. 225.

14 L. R. Gay, Eductional Research: Competencies for Analysis and Applicatio, Fifth Edition (United States of America : 
menginterprestasikan berarti menggunakan hasil analisis untuk memperoleh arti atau makna.

Adapun teknik interpretasi data dapat dilakukan dengan cara yaitu (a) hubungkan hasil-hasil analisis dengan teori-teori pada bab sebelumnya; (b) hubungkan atau tinjauan dari teori yang relevan dengan permasalahan yang dihadapi; (c) perluaslah hasil analisis dengan mengajukan pertanyaan berkenaan dengan hubungan, perbedaan antara hasil analisis, penyebab, implikasi dari hasil analisis sebelumnya; (d) hubungkan temuan dengan pengelaman pribadi; dan (e) berilah pandangan kritis dari hasil analisis yang dilakukan. ${ }^{15}$

Dalam penelitian ini hasil analisa bahan hukum sebagaiman tersebut di atas akan diinterpretasikan dengan menggunakan metode interpretasi sistematis dan teleologis. ${ }^{16}$ Pemilihan interpretasi sistematis ditujukan untuk menetukan struktur hukum dalam penelitian ini. Interpretasi sistematis (systematische interpretatie, dogmatische interpretatie) adalah menafsirkan dengan memperhatikan naskah-naskah hukum lain. Jika ditafsirkan adalah pasal-pasal suatu undang-undang, ketentuan yang sama apalagi satu asas dalam peraturan lainnya juga harus dijadikan acuan. Dalam penafsiran ini mencari ketentuan-ketentuan yang ada didalamnya saling berhubungan sekaligus apakah hubungan tersebut menentukan makna selanjutnya. Akan

Florida International University, 1996), h. 458459.

${ }^{15}$ L. R. Gay, Eductional...., h. 461.

16 Interpretasi dibedakan menjadi interpretasi berdasarkan kata-kata undangundang (leterlijk), interpretasi gramatikal, interpretasi berdasarkan kehendak pembentuk undang-undang, interpretasi sistematis, interpretasi historis, interpretasi sosiologis, interpretasi sosio-historis, interpretasi filosofis, interpretasi teleologis, interpretasi holistik dan interpretasi holistik tematis-sistematis. Lihat Jimly Asshiddiqie, Teori \& Aliran Penafsiran Hukum Tata Negara, (Jakarta : Ind. Hill. Co., 1997), h. 17-18. tetapi, dalam hubungan tatanan hukum yang tidak terkodifikasi, merujuk pada sistem dimungkinkan sepanjang karakter sistematis dapat diasumsikan (diandaikan).

Adapun interpretasi teleologis (what does the articles would like to archieve) yang merupakan yang metode penafsiran yang difokuskan pada penguraian atau formulasi kaidah-kaidah hukum menurut tujuan dan jangkauannya. Tekanan tafsiran pada fakta bahwa kaidah hukum terkandung tujuan atau asas sebagai landasan dan bahwa tujuan atau asas tersebut memengaruhi interpretasi. Dalam penafsiran demikian juga diperhitungkan konteks kenyataan kemasyarakatan yang aktual. ${ }^{17}$

Menurut Hoft, penafsiran teleologis memiliki fokus perhatian bahwa fakta pada norma hukum mengandung tujuan untuk melindungi kepentingan tertentu sehingga ketika ketentuan tersebut diterapkan maksud tersebut harus dipenuhi, penafsiran ini selanjutnya memperhitungkan konteks kemasyarakatan aktual. ${ }^{18}$

Cara ini tidak terlalu diarahkan untuk menemukan pertautan pada kehendak dari pembentuk undang-undang saat membentuknya dan kemudian dituangkan dalam bentuk uraian logis dan sistematis guna memperoleh kejelasan penyelesaian lalu ditarik kesimpulan guna menjawab permasalah penelitian secara deduktif yaitu dari hal yang bersifat umum menunju yang hal bersifat khusus.

Data yang diperoleh sebagaimana tersebut di atas, akan di analisa dengan menggunakan teknik analisa data deskriptif kualitatif, komprehensif dan lengkap, yaitu menguraikan data dalam bentuk kalimat yang disusun secara sistematis, lengkap dan rinci menurut kerangka bahasan yang sudah ditentukan

17 Jimly Asshiddiqie, Teori....., h. 30.

18 B. Arief Sidharta (Penerjemah), Meuwissen tentang Pengembangan Hukum, Ilmu Hukum, Teori Hukum dan Filsafat Hukum, (Bandung : PT. Rafika Aditama, 2009), h. 56-57. 
menurut urutan angka, sehingga memudahkan dalam memberikan arti terhadap data sesuai dengan tujuan penelitian dan akhirnya dapat ditarik kesimpulan. ${ }^{19}$

Adapun teknik analisis data atau bahan hukum tersebut dilakukan melalui tahapan-tahapan sebagai berikut : pertama, pendeskripsian atau penggambaran, dilakukan untuk menentukan isi atau makna dari suatu bahan hukum disesuaikan dengan pokok permasalahan yang ada. Pada tahapan ini dilakukan pemaparan serta penentuan terhadap makna dari aturan-aturan hukum yang terdapat didalam peraturan perundangundangan di bidang sarana dan prasarana umum, maupun pemaparan terhadap berbagai pendapat sarjana yang terkait.

Kedua, dokumentasi adalah catatan peristiwa yang sudah berlalu, bisa berbentuk tulisan, gambar atau karyakarya monumental dari seseorang. ${ }^{20}$ Dalam observasi ini, maka peneliti menggunakan dokumentasi yang berupa tulisan.

Ketiga, interpretasi. Tahap interpretasi dilakukan untuk memahami makna dari suatu norma, terutama dalam hal ditemukan norma-norma yang kabur (vogue norm), setelah bahan-bahan hukum dapat diindentifikasi secara jelas, maka dilanjutkan melakukan sitermatisasi.

Keempat, sistematisasi. Pada tahapan sistematisasi akan dilakukan pemaparan berbagai pendapat hukum dan hubungan hirarkhis antara aturan-aturan hukum yang berkaitan dengan isu hukum dalam penelitian ini. Pada tahapan ini juga dilakukan koherensi antara berbagai aturan hukum dengan pendapat hukum dari para sarjana yang berhubungan agar dapat dipahami dengan baik. Bahan hukum yang telah tersistematisasi, baik berupa pendapat hukum maupum aturan-aturan

19 Abdulkadir Muhammad, Hukum dan Penelitian Hukum, (Bandung : PT. Citra Aditya Bakti, 2004)., h. 152.

20 Jonathan Sarwono, Metode Penelitian Kuantitatif dan Kualitatif, (Yogyakarta : Graha Ilmu, 2006), h. 225. hukum selanjutnya dilakukan evaluasi dan diberikan pendapat atau argumentasi disesuaikan dengan koherensinya terhadap permasalahan yang dibahas.

Setelah proses analisis dilakukan, maka penarikan kesimpulan dilakukan dengan menggunakan metode induktif, yakni bahwa generalisasi yang menjadi kesimpulan dalam lingkup penelitian ini ditarik dengan menganalisis data melalui kasus dari obyek yang diteliti.

\section{PEMBAHASAN}

\section{Penelitian}

\section{Gambaran Umum Obyek}

Berbagai cara penyelesaian sengketa dapat dilakukan seperti melalui negosiasi, arbitrase dan lain-lain seperti yang diatur dalam UU No. 30 Tahun 1999 atau dapat juga melalui pengadilan. Tapi sulitnya penyelesaian sengketa melalui pengadilan ataupun arbitrase yang membutuhkan waktu yang panjang dan prosesnya yang berbelit-belit, sehingga Bank Indonesia mengupayakan suatu penyelesaian sengketa yang dapat dilaksanakan dengan proses sederhana, murah dan cepat melalui lembaga mediasi perbankan syariah. Tujuan dari pembentukan lembaga mediasi perbankan syariah ini adalah agar hak-hak nasabah sebagai pemakai jasa perbankan syariah dapat terpenuhi dengan baik. Diharapkan dengan adanya Peraturan Bank Indonesia (PBI) ini akan tercipta iklim perbankan syariah yang semakin kondusif.

Mediasi perbankan syariah adalah cara yang diambil oleh nasabah apabila pengaduannya tidak mendapatkan tanggapan yang positif dari pihak bank, dan belum mendapatkan solusi terbaik bagi permasalahannya. Sebagai langkah pertama dari penyelesaian sengketa, terlebih dahulu keluhan dari nasabah itu harus bisa dilaporkan ke bank yang bersangkutan untuk diproses melalui mekanisme pengaduan nasabah yang ada di setiap bank. Bank indonesia mengatur tentang pengaduan nasabah ini dalam 
Peraturan Bank Indonesia Nomor 7/7/PBI/2005.

Yang dimaksud dengan mediasi perbankan syariah adalah proses penyelesaian sengketa yang melibatkan mediator untuk membantu para pihak yang bersengketa guna mencapai penyelesaian dalam bentuk kesepakatan sukarela terhadap sebagian ataupun seluruh permasalahan yang disengketakan. Bantuan yang diberikan dilakukan dengan cara memfasilitasi penyelesaian sengketa dengan cara memanggil, mempertemukan, mendengar serta memotivasi nasabah dan bank untuk mencapai kesepakatan tanpa memberikan rekomendasi ataupun putusan.

\section{Penyajian Data}

Menurut pendapat Moore C.W dalam naskah akademis mediasi, mediasi adalah interensi terhadap suatu sengketa atau negoisasi oleh pihak ketiga yang dapat diterima, tidak mempunyai kewenangan untuk mengambil keputusan dalam memantu para pihak yang berselisih dalam upaya mencari kesepakatan secara sukarela dalam menyelesaikan permasalahan yang disengketakan. Mediasi adalah upaya para pihak yang bersengketa untuk menyelesaikan sengketa melalui perundingan dengan bantuan pihak lain yang netral. Mediasi adalah cara penyelesaian sengketa melalui proses perundingan untuk memperoleh kesepakatan para pihak dengan dibantu mediator. Kesimpulan mediasi apabila diuraikan mengandung unsur-unsur sebagai berikut:

a) Mediasi adalah sebuah proses penyelesaian sengketa berdasarkan asas kesukarelaan melalui suatu perundingan.

b) Mediator yang terlibat bertugas membantu para pihak yang bersengketa untuk mencari penyelesaian,

c) Mediator yang terlibat harus diterima oleh para pihak yang bersengketa.

d) Mediator tidak boleh memberi kewenangan untuk mengambil keputusan selama perundingan berlangsung.

e) Tujuan mediasi adalah untuk mencapai atau mnghasilkan kesimpulan yang dapat diterima dari pihak-pihak yang bersengketa .

Prinsip-prinip mediasi yang digunakan pada daarnya adalah sebagai berikut:

a) Kewajiban partisipasi seluruh pihak dalam prose mediasi.

b) Upaya maksimal untuk mencapai mufakat.

c) Penggunaan pendekatan rekturisasi dengan pola best commerciaal practice.

d) Menghormati hak-hak para pihak yang terkait.

Dari penjelasan diatas dapat dijelaskan tentang karakteristik dari prinsip dalam suatu mediasi yaitu:

a) Accessible

Setiap orang yang membutuhkan dapat menggunakan mediasi, tidak ada suatu prosedur yang kaku dalam kaitannya dengan karakteristik antara mediasi yang satu dengan yang lainnya.

b) Voluntary

Setiap orang yang mengambil bagian dalam proses mediasi harus sepakat dan dapat memutuskan setiap saat apabila ia menginginkan mereka tidak dapat memaksa untuk dapat menerima suatu hasil mediasi apabila dia meras hasil mediasi tidak menguntungkan atau memuaskan dirinya.

c) Confidential

Para pihak ingin merasa bebas untuk menyatakan apa saja dan menjadi terbuka untuk kepentingan mediasi.

d) Fasilitative

Mediasi merupakan kreatifitas dan pendekatan pemecahan masalah terhadap persoalan yang dihadapi dan bergantung pada mediator untuk membantu para pihak mencapai kesepakatan dengan tetap dan tidak dapat memihak.

Dasar hukum mediasi adalah Undang-Undang No.4 Tahun 2004 pasal 16 ayat (2) tentang kekusaan kehakiman 
yang berbunyi ketentuan sebagaimana dimaksud pada ayat (1) tidak menutup usaha penyelesaian perkara perdata dengan cara perdamaian. Undang-Undang No 30 Tahun 1990 tentang arbitrese dan alternative penyelesaian sengketa, yang lebih mempertegas keberadaan lembaga mediasi sebagai lembaga alternatif penyelesaian sengketa. Menurut ketentuan dari peraturan Mahkamah Agung bahwa setelah dilakukan evaluasi terhadap pelaksanaan prosedur mediasi di Pengadilan berdasarkan Peraturan Mahkamah Agung Republik Indonesia No 2 Tahun 2003 ternyata ditemukan beberapa permasalahan yang bersumber dari Peraturan Mahkamah Agung Tersebut, sehingga Peraturan Mahkamah Agung Republik Indonesia No 2 Tahun 2003 direvisi dengan maksud untuk lebih mendayagunakan mediasi yang terkait dengan proses berperkara di Pengadilan. Sehingga Peraturan Mahkamah agung No 2 Tahun 2003 diubah menjadi Peraturan Mahkamah Agung No 1 Tahun 2008 tentang prosedur mediasi di Pengadilan (Perma No 1 Tahun 2008).

Mediasi mempunyai suatu tujuantujuan. Adapun tujuan dari mediasi adalah sebagai berikut:

a) Mencapai atau menghasilkn kesepakatan yang dapat diterima oleh para pihak yang bersengketa guna mengakhiri sengketa.

b) Merupakan sebuah proses penyelesaian sengketa berdasarkan perundingan atau negosiasi.

c) Mediasi lazimnya terjadi setelah para pihak yang bersengketa melakukan negosiasi (dan gagal mencapai kesepakatan). Karena itu sering dinyatakan bahan mediasi adalah merupakan suatu negosiasi dengan melibatkan pihak ketiga yang memiliki pengetahuan tentang prosedur negosiasi yang efektif dan berfungsi membantu para pihak yang bersengketa mengkoordinasikan negoisinya agar berjalan efektif dan efisien.Tujuan mediasi dalam hal ini dibagi menjadi dua bagian yaitu tujuan utama dan tujuan tambahan.Yang dimaksud dengan tujuan utama yaitu membantu mencarikan jalan keluar atau alternative penyelesaian atas sengketa yang timbul diantara para pihak yang disepakati dan dapat diterima oleh para pihak yang bersengketa.

Dengan demikian proses negosiasi adalah proses yang forward looking dan bukan backward looking. Yang hendak dicapai bukanlah mencari kebenaran dan atau dasar hukum yang diterapkan namun kepada penyelesaian masalah." the goal is not truth finding or low imposing but problem solving"(Lovenheim, 1996: 1.4). Sedangkan untuk tujuan tambahan disini yaitu dengan melalui proses mediasi diharapkan dapat dicapai terjalinnya komunikasi yang lebih baik diantara para pihak yang bersengketa dan menjadikan para pihak yang bersengketa dapat mendengar, memahami alasan atau penjelasan atau argumentasi yang menjadi dasar atau pertimbangan pihak lain. Dengan adanya pertemuan tatap muka, diharapkan dapat mengurangi rasa marah atau bermusuhan antara pihak-pihak yang satu dengan yang lainnya".

3. Analisis Data

Proses mediasi dalam hal ini dibagi menjadi dua tahap yaitu pra mediasi dan tahap mediasi, yang mana sudah diatur dalam PERMA No 1 Tahun 2008 yaitu :

a. Tahap pra Mediasi

Pada hari sidang yang telah ditentukan yang telah ditentukan oleh kedua belah pihak, hakim mewajibkan para pihak untuk melakukan mediasi. Kehadiran dari pihak turut Tegugat tidak menghalangi pelaksanaan mediasi, sehingga hakim melalui kuasa hukum atau langsung kepada para pihak mendorong para pihak untuk berperan langsung atau aktif dalam proses mediasi.kuasa hukum para pihak berkewajiban mendorong para pihak sendiri berperan langsung atau aktif dalam proses mediasi. hakim wajib menunda proses persidangan perkara untuk memberikan kesempatan kepada 
para pihak menempuh mediasi dan hakim wajib menjelaskan

\section{b. Tahap Mediasi}

Ketika para pihak sepakat untuk melakukan proses mediasi, yang mana para pihak berkehendak untuk mencapai kesepakatan penyelesaian atas sengketanya. Mediasi akan berjalan dengan kondisi-kondisi sebagai berikut :

1) Mediator adalah seorang fasilitator yang akan membantu para pihak untuk mencapai kesepakatan yang dikehendaki oleh para pihak.

2) Mediator tidak memberi nasehat atau pendapat hukum.

3) Para pihak yang bersengketa dapat meminta pendapat par ahli baik dari sisi hukum lainnya selama proses mediasi berlangsung.

4) Mediator tidak dapat bertindak sebagai penasehat hukum terhadap salah satu pihak dalam kasus yang sama ataupun yang berhubungan dan ia juga tidak dapat bertindak sebagai arbiter atau kasus yang sama.

5) Para pihak paham agar proses mediasi dapat berjalan dengan baik maka diperlukan proses komunikasi yang terbuka dan jujur, selanjutnya segala bentuk negosiasi dan pernyataan baik tertulis maupun lisan yang dibuat dalam proses mediasi akan diperlukan sebagai informasi yang bersifat tertutup dan rahasia.

Selanjutnya, setelah Bank Indonesia sebagai pelaksana fungsi mediasi perbankan syariah menerima pengajuan penyelesaian sengketa oleh nasabah kemudian Bank Indonesia memanggil bank yang bersangkutan untuk melakukan klarifikasi mengenai pokok permasalahan yang dilaporkan oleh nasabah. Hal ini sesuai dengan pasal 7 ayat (1) yaitu : "Dalam hal nasabah atau perwakilan nasabah mengajukan penyelesaian kepada Bank Indonesia, Bank wajib memenuhi panggilan Bank Indonesia". Tujuan dari pemanggilan ini adalah untuk meminta informasi mengenai permasalahan yang diajukan oleh nasabah dan upaya-upaya penyelesaian sengketa apa saja yang dilakukan oleh bank. Setelah mengetahui pokok permasalahan dan tidak ada titik temu dalam proses pengaduan nasabah tersebut, kemudian Bank Indonesia memanggil kedua belah pihak untuk menjelaskan tata cara penyelesaian sengketa melalui mediasi perbankan syariah.

Apabila kedua belah pihak sepakat menggunakan mediasi perbankan syariah sebagai upaya penyelesaian sengketa, maka kedua pihak wajib menandatangani perjanjian mediasi (agreement to mediate). Adapun isi dari perjanjian mediasi ini disebutkan dalam Pasal 9 ayat (1) yaitu: proses mediasi dilaksanakan setelah nasabah atau perwakilan nasabah dan bank menandatangani perjanjian mediasi yang memuat:

a. Kesepakatan untuk memilih mediasi sebagai alternative penyelesaian sengketa; dan

b. Persetujuan untuk patuh dan tunduk pada aturan mediasi yang ditetapkan oleh Bank Indonesia.

Kemudian dalam hal perjanjian Mediasi telah ditandatangani, maka bank dan nasabah atau perwakilan nasabah wajib untuk mengikuti dan mentaati perjanjian tersebut (pasal 9 ayat (2)). Apabila dalam prakteknya nasabah atau bank tidak mempunyai cukup waktu untuk mengikuti proses mediasi dari awal sampai akhir karena berbagai alasan, maka mereka boleh untuk menunjuk seseorang untuk menggantikan posisinya melalui suatu surat kuasa khusus. Dengan adanya surat kuasa khusus tersebut, maka perwakilan nasabah atau perwakilan bank yang telah ditunjuk akan mempunyai hak untuk mengambil keputusan dalam proses mediasi yang akan berjalan. Penunjukan perwakilan nasabah atau perwakilan bank dengan komitmen penuh dimaksudkan agar proses mediasi dapat berjalan dengan lancer dan cepat, sesuai dengan tujuan awal mediasi. Hal ini sesuai dengan pasal 10 ayat (1) yang menyatakan bahwa nasabah dan bank dapat memberikan kuasa 
kepada pihak lain dalam proses mediasi. Sedangkan ayat (2) berbunyi: "Pemberian kuasa sebagaimana dimaksud pada ayat (1) dilakukan dengan surat kuasa khusus yang paling sedikit mencantumkan kewenangan penerima kuasa untuk mengambil keputusan.

Untuk dapat melaksanakan fungsi mediasi, maka Bank Indonesia menunjuk seorang mediator (pasal 5 ayat (1)). Mediator yang ditunjuk oleh Bank Indonesia adalah pegawai di lingkungan Bank Indonesia sendiri yang berpengalaman dalam menangani mediasi perbankan sesuai dengan syarat yang ditetapkan oleh PBI ini. Adapun pasal 5 ayat (2) mengatur syarat-syarat yang harus dimiliki oleh mediator yaitu:

a. memiliki pengetahuan di bidang perbankan, keuangan, dan atau hukum;

b. Tidak mempunyai kepentingan finansial atau kepentingan lain atas penyelesaian sengketa; dan

c. Tidak memiliki hubungan sedarah atau semenda sampai dengan derajat kedua dengan nasabah atau perwakilan nasabah dan bank.

Meskipun yang ditangani adalah sengketa perdata antara bank dengan nasabah, tetapi mediator yang ditunjuk oleh Bank Indonesia haruslah orang yang mempunyai integritas dan dijamin independensinya. Selain itu, karena mediator dituntut untuk dapat bersikap netral dan tidak memihak terhadap kedua belah pihak, sehingga mediator tidak diperkenankan memberikan rekomendasi dan keputusan atas penyelesaian sengketa kepada nasabah bank. Dalam hal proses mediasi yang akan dilaksanakan, para pihak tidak dapat meminta pendapat hukum atau jasa konsultasi hukum kepada mediator, sehingga kesepakatan yang dihasilkan dari proses mediasi tersebut merupakan kesepakatan sukarela antara nasabah dan bank dan bukan rekomendasi dari mediator.

Selanjutnya, nasabah ataupun bank dengan alasan apapun tidak dapat mengajukan tuntutan hukum terhadap mediator, pegawai maupun Bank Indonesia sebagai fungsi Mediasi Perbankan syariah, baik atas kerugian yang mungkin timbul karena pelaksanaan atau eksekusi Akta kesepakatan, maupun oleh sebab-sebab lain yang terkait dengan pelaksanaan mediasi.

1. Tahap Mediasi:

Tahap mediasi dimulai ketika para pihak sepakat untuk menggunakan mediasi perbankan syariah sebagai alternatif penyelesaian sengketa dan menandatangai Perjanjian Mediasi agreement to mediate). Dengan ditandatanganinya perjanjian mediasi ini maka para pihak harus patuh dan taat terhadap aturan mediasi perbankan syariah. Pelaksanaan proses mediasi perbankan syariah sampai dengan penandatangan Akta Kesepakatan membutuhkan waktu yang relatif singkat yaitu paling lama 30 (tiga puluh hari kerja yang dimulai dari penandatanganan perjanjian mediasi (agreement to mediate). Selain itu, dengan kesepakatan para pihak maka jangka waktu proses mediasi dapat diperpanjang sampai dengan 30 (tiga puluh) hari kerja berikutnya (pasal 11 ayat (1) dan (2)). Perpanjangan waktu ini dapat dilakukan apabila menurut penilaian mediator masih terdapat prospek untuk tercapai kesepakatan sedangkan jangka waktu proses mediasi hamper berakhir.

Dalam mengikuti proses Mediasi sebagai penyelesaian sengketa, maka nasabah dan bank bersedia untuk: pertama, melakukan proses mediasi dengan itikad baik, kedua, bersikap kooperatif dengan mediator selama proses mediasi berlangsung, dan ketiga, menghadiri pertemuan mediasi sesuai dengan Tanggal dan tempat yang telah disepakati. Hal ini bertujuan agar proses mediasi dapat berjalan dengan lancar dan sesuai dengan waktu yang telah disepakati bersama. Selain itu juga demi tercapainya kesepakatan bersama maka nasabah dan bank wajib untuk menyampaikan dan mengungkapkan informasi penting terkait dengan pokok sengketa dalam pelaksanaan 
mediasi. Dan untuk menjaga kerahasiaan dari proses mediasi ini maka seluruh informasi dari para pihak yang berkaitan dengan proses mediasi tidak dapat disebarluaskan untuk kepentingan pihak lain diluar pihak-pihak yang terlibat dalam proses mediasi ini yaitu nasabah, bank dan mediator.

Kemudian dalam hal proses mediasi mengalami kebuntuan dalam upaya kesepakatan, baik untuk sebagian maupun keseluruhan pokok sengketa dimana para pihak tidak ada yang mengalah, maka mediator dapat mengambil tindakan antara lain: (a). menghadirkan pihak lain sebagai narasumber atau sebagai tenaga ahli untuk mendukung kelancaran proses mediasi, (b). menangguhkan proses mediasi sementara dengan tidak melampaui batas waktu proses mediasi; atau (c) menghentikan proses mediasi.

2. Tahap Hasil Mediasi:

Akta kesepakatan yang ditandatangani oleh nasabah dan bank sudah mempunyai kekuatan mengikat para pihak dan bersifat final. Pasal 13 menjelaskan bahwa bank wajib melaksanakan hasil penyelesaian sengketa perbankan syariah yang telah disepakati dan dituangkan dalam Akta Kesepakatan. Akta kesepakatan tersebut merupakan hasil musyawarah yang panjang antara bank dan nasabah sehingga didapatkan keputusan win-win solutin bagi para pihak.

\section{KESIMPULAN}

Berdasarkan pemaparan di atas maka dapat disimpulkan sebagai berikut:

1. Mediasi sebagai salah satu bentuk alternatif penyelesaian sengketa diharapkan dapat memenuhi kebutuhan tersebut. Kecenderungan yang terjadi dalam masyarakat saat ini terlihat bahwa mediasi sudah menjadi media masyarakat untuk menyelesaikan masalah atau sengketa yang dialaminya. Hal ini dapat diketahui dengan banyak berdirinya lembagalembaga yang menyediakan jasa mediasi, misalnya BANI dll.
2. Mekanisme penyelesaian sengketa antara nasabah dan bank pada Kantor Bank Indonesia Padang ditempuh melalui dua tahap. Pertama, bank wajib menyelesaikan terlebih dahulu sengketa dengan nasabahnya sesuai Peraturan Bank Indonesia (PBI) No.7/7/PBI/2005 tentang Penyelesaian Pengaduan Nasabah. Kedua, apabila sengketa belum dapat diselesaikan dengan baik, nasabah bank dapat mengajukan permohonan penyelesaian sengketa melalui mediasi sesuai PBI No. 8/5/PBI/2006 tentang Mediasi Perbankan syariah. Fungsi mediasi perbankan syariah yang dilaksanakan pada Kantor Bank Indonesia hanya terbatas pada penyediaan tempat, membantu nasabah dan bank untuk mengemukakan pokok permasalahan yang menjadi sengketa, penyediaan nara sumber, dan mengupayakan tercapainya kesepakatan penyelesaian sengketa antara nasabah dan bank.

\section{DAFTAR PUSTAKA}

Abdullah abdul Hasan At Tariqi, Ekonomi ISlam Prinsip Dasar dan Tujuan, (Yogyakarta: Magistra Insane Press, 2004)

Aziz Dahlan Abdul, Enkslopedi Hukum Islam, (Jakarta: PT Ichtiar Baru Vanvove, 1997)

A Rahman Ritonga dan Zainuddin, Fiqh Ibadah, (Jakarta: Gaya Media Pratama, 2002)

A Djazuli, Lembaga-lemaga Perekonomian umat, sebuah pengantar, (Jakarta, Rajawali Grafindo Persada, 2002)

Ditjen Bimas Islam dan Penyelengharaan Ibadah Haji, Realitas \& Tantangan Penyelenggaraan Ibadah Haji, (Jakarta: Ditjen BPIH, 2003)

Fadhul ,Fikih abdullah Ibnu Mas'ud ra. fi Fiqh'il Muamalat, Diraasah

Gufron A. Mas'adi, FiqhMuamalahKonsektual, (Jakarta: Raja Grafindo Persada, 2002) 
Gunawan Imam, Metode Penelitian Kualitatif Teori Dan Praktik, (Jakarta: Bumi Aksara, 2016)

Wahbah Alzuayly, Zakat Kajian Berbagai Mazhab ( Bandung: PT, Remaja Rosda Karya, 2008)

Jeni Susyanti, Pengelolaan Lembaga Keuangan Syariah ( Malang: 42, 2016)

M. Hasan Ali ,Berbagai macam Transaksi dalam Islam (Fiqh Mu'amalat) (Jakarta: Rajawali Pres, 2003)

Muaqarranah (Saudi Arabia , Ummul Qura, Perss, 2004),

Nurul Huda,Purnama Putra, Novarini, yosi Mardoni, Baitul Mall Wa Tamwil sebuah tinjauan teoritis (Jakarta: Amzah,2016)

Akhmad Mujahidin, Hukum Perbankan Syariah ( Jakarta:Pt Raja Grafindo Persada, 2016)

Iqbal M .Aris Ali, Kekuatan Entitas Syariah Yang Terlupakan (Jakarta:Pt Raja Grafindo Persada, 2016)

Kantor Wilayah Kementerian Agama Provinsi Jatim, Fiqh Zakat ( Surabaya, 2004)

Direktotat Jenderal Bimbingan Masyarakat Islam, Direktorat Pemberdayaan zakat, ( Jakarta,2012)

Direktotat Jenderal Bimbingan Masyarakat Panduan Pengembangan Usaha bagi Mustahiq ( Jakarta,2009)

Direktotat Jenderal Bimbingan Masyarakat, Panduan Organisasi Pengelola Zakat ( Jakarta,2010)

Proyek Pembinaan Zakat dan Wakaf, Pedoman Zakat 9 Seri ( Jakarta: 1985/1986)

Direktotat Jenderal Bimbingan Masyarakat Islam,Direktotat Jenderal Pemberdayaan Zakat ( Jakarta: 2012 )

Himpunan Peraturan Perundang-Undangan Republik Indonesia, UndangUndang Pengelolaan Zakat nomor 23 Tahun 2011 ( Jogjakarta: 2011)

M.Ma'ruf Abdullah, Hukum Keuangan Syariah Pada Lembaga keuangan bank dan Non Bank (Jogjakarta: Aswaja Pressindo,2016)

Direktotat Jenderal Bimbingan Masyarakat Islam, Direktorak Pemberdayaan zakat, Standar Operasional Prosedur Lembaga Pengellolaan Zakat,( Jakarta:2011)

Mukhtar, Metode Praktis Penelitian Deskriptif Kualitatif, (Jakarta: Referensi, 2013)

Nazir Habib dan Muhammad Hasanuddin, Ensiklopedi Ekonomi dan Perbankan Syariah, (Bandung: Kafa Publising, 2008)

Sjahdeini, Perbankan Islam dan Kedudukannya Dalam Tata Hukum Perbankan Indonesia, (Jakarta: Pustaka Utama Grafiti, 1999).

Soemitra Andri, Bank dan Lembaga Keuangan Syariah, (Jakarta: Kencana, 2009),

Sumitro Warkum, Asas-asas Perbankan Islam dan Lembaga-lembaga terkait BMUI dan Tafaku, (Jakarta: PT Raja Grafindo, 1996)

Sutedi Andrian, Perbankan syariah: Tinjauan dan Beberapa segi hukum, (Jakarta: Ghalia Indonesia, 2009,)Soerjono Soekanto dan Sri Mamudji, Penelitian Hukum Normatif, (Jakarta: PT Grafindo persada, 2006)

Sugiono, Metode Penelitian Kuantitatif, Kualitatif dan $R \& D$ (Bandung: Alfabeta, 2014)

Prastowo Andi, Metode Penelitian Kualitatif dalam Perspektif Rancangan Penelitian, ( Jogjakarta: Ar-rum Media, 2014) 